\title{
US policy contributions to agricultural commodity price fluctuations, 2006-12
}

\section{Gordon C. Rausser ${ }^{1}$ and Harry de Gorter ${ }^{2}$}

March 2013

\begin{abstract}
Since 2006, global prices and price volatility for foodgrain commodities have spiked frequently and dramatically. Such spikes have had the heaviest economic and social impact on developing nations, where agriculture accounts for a sizable portion of economic activity. We demonstrate how US public policies have contributed to these spikes. We first assess the impacts of US agricultural and macroeconomic policies on basic food commodity markets in the United States and their spillover effects on world markets prior to 2006. We then focus on new causal mechanisms that have emerged since 2006, sourced with energy and environmental policies. We assess the emergence of US biofuel policies, highlighting how these policies have interacted with each other and with biofuel policies in the rest of the world. This assessment focuses on the role of such policies in the integration of fuel and foodgrain prices. We also analyse the political economy of US biofuel policies, the changing US political landscape, and current Farm Bill politics and their linkages to biofuels. We demonstrate that the 'iron triangle' that once influenced governmental intervention in programme commodity markets has expanded into an 'iron maze' of environmental, energy, and agricultural organized interest groups that continues to evolve.
\end{abstract}

Keywords: agriculture in international trade, agricultural policy, environmental economics, food policy, food security, price level

JEL classification: D78, F52, Q17, Q18

Copyright (C) UNU-WIDER 2013

${ }^{1}$ University of California, Berkeley, CA: email: rausser@berkeley.edu; ${ }^{2}$ Charles H. Dyson School of Applied Economics and Management, Cornell University, Ithaca, NY: email: hd15@cornell.edu

This study has been prepared within the UNU-WIDER project 'Political Economy of Food Price Policy' directed by Per Pinstrup-Andersen.

UNU-WIDER gratefully acknowledges the financial contributions to the research programme from the governments of Denmark, Finland, Sweden, and the United Kingdom.

This publication was supported by an agreement with Cornell University Division of Nutritional Sciences under Subagreement No. 60891-9461. 


\section{Acknowledgements}

The authors would like to thank the three anonymous reviewers for their helpful comments, suggestions, and constructive criticisms. The final draft of the paper also benefited from Per Pinstrup-Andersen's suggestions and comments.

The World Institute for Development Economics Research (WIDER) was established by the United Nations University (UNU) as its first research and training centre and started work in Helsinki, Finland in 1985. The Institute undertakes applied research and policy analysis on structural changes affecting the developing and transitional economies, provides a forum for the advocacy of policies leading to robust, equitable and environmentally sustainable growth, and promotes capacity strengthening and training in the field of economic and social policy making. Work is carried out by staff researchers and visiting scholars in Helsinki and through networks of collaborating scholars and institutions around the world. www.wider.unu.edu publications@wider.unu.edu

UNU World Institute for Development Economics Research (UNU-WIDER)

Katajanokanlaituri 6 B, 00160 Helsinki, Finland

Typescript prepared by Liisa Roponen at UNU-WIDER.

The views expressed in this publication are those of the author(s). Publication does not imply endorsement by the Institute or the United Nations University, nor by the programme/project sponsors, of any of the views expressed. 


\section{Introduction}

The recent food commodity price boom and bust follows the pattern of those that preceded it, with broad and sharp co-movement of commodity prices. Such booms and busts have the heaviest economic and social impact on developing nations, where agriculture accounts for a sizable portion of economic activity, households spend a large share of their disposable income on food commodities, and economies depend heavily on food commodity trade. Typically, food commodity price spikes_and volatility in general-resonate with populists and affect social welfare more dramatically than most (if not all) other asset price volatility or spikes.

For storable food commodities, price spikes and volatility result from a sequence of supply and/or demand shocks that reduce inventories to low levels. ${ }^{1}$ Although the specific factors that cause each dramatic increase in volatility and/or price are nuanced, common causal forces drive these rapid changes. These causal forces are sourced with market structures across food commodity groups. Causes of volatility include the dynamics of commodities stockholding and speculation; macroeconomic phenomena observed through nominal interest rates, real interest rates, and exchange rates; cross-commodity linkages or general equilibrium effects through factor substitution and input costs; and governmental policies. When such events combine with macroeconomic fiscal and monetary policies that result in disequilibria between nominal and real rates of interest, the incentives for stockholding change. Moreover, export quotas and other trade restrictions can aggravate (and have aggravated) the volatility of food commodity prices and send the wrong price signals to domestic markets (Carter, Rausser and Smith 2011). To the extent that such price volatility is not temporary, the crosscommodity linkages through competition for land allocation and demand substitutability often create spillover effects from one food commodity to another. Still another causal force that has emerged over our recent history is the growing global demand-sourced with higher income levels in emerging markets—-for higher-quality sources of protein.

Public policy responses frequently amplify the consequences of these internal and external market forces. In this paper, we demonstrate how US public policies have contributed to recent global price spikes and volatility. We examine agricultural and macroeconomic policies, which have always played a significant role in generating grain price volatility. But we also focus on new causal mechanisms that have emerged since 2006 in the form of energy and environmental policies. These policies have made biofuel and foodgrain prices interdependent. We also highlight the ways in which various US biofuel policies have interacted both with each other and with biofuel policies in the rest of the world. For example, US biofuel policies contributed to the 2007-08 episode of food price volatility (which was magnified by both US fiscal and monetary policies). Since biofuel policies in the United States and other OECD countries interact with fossil fuel energy markets, the level and variability of crop prices are highly susceptible to changes in oil prices and macroeconomic conditions, especially those that cause major shifts in transportation fuel demand.

The net effect of these new causal mechanisms is that US biofuel policies have ultimately increased rather than lowered world prices (without reducing volatility). High oil prices elevated crop prices in 2006-08; lower oil prices in 2008-09 helped make crop prices

\footnotetext{
1 The linkages between supply and demand shifts, inventory situations, and commodity price changes are described in more detail in Hochman et al. (2011), Wright (2011), and Carter, Rausser and Smith (2012).
} 
plummet. Lately, crop prices have risen again almost to their 2008 peak levels, and some studies have even argued that oil prices have led increased foodgrain commodity prices (e.g., Baffes and Haniotis 2010). In short, the economics of commodity price volatility have recently become more complex. Interaction effects now depend not only on the source of the shock (oil prices versus crop supply/demand shocks), and on which biofuel policy determines the world biofuel market price (e.g., tax credit versus mandate), but also on the interactions across the various environmental, energy, and agricultural policy instruments within a country as well as across countries.

US biofuel policies were a critical factor in instigating the increase in foodgrain commodity prices that began to emerge in 2006 (Carter, Rausser and Smith 2012), ${ }^{2}$ as were biofuel policies in the rest of the world, especially in the European Union and Brazil. US biofuel, agricultural, and macroeconomic policies contributed substantially to the rise in foodgrain commodity prices that emerged in $2008 .^{3}$ From that point forward, US fiscal and monetary policies, combined with US biofuel policies, generated the roller-coaster ride that lasted from 2008 through 2012. For example, when the United States negotiated the release of Japanese rice stocks, this move allegedly caused rice prices to begin to decline from their peak in 2008 (Slayton 2010). But US monetary and fiscal policies that were devised in order to respond to the 2008 financial crisis - which itself was induced by failed regulatory and financial policies — substantially affected commodity prices and thus volatility.

US energy and environmental policies have also played a role in the evolving politicaleconomic landscape in which traditional agricultural policies are determined. In one clear instance, the deliberations concerning the upcoming US Farm Bill have been substantially tilted towards revenue insurance programmes (in place of direct and countercyclical payments) and allowed farmers to be subsidized by high prices (Zulauf and Orden 2012; Babcock and Paulson 2012). The expiration of the ethanol tax credit and import tariff at the end of 2011 could also be described as a policy response to high and volatile crop prices. Although these policy changes had little immediate impact, there are longer-run consequences.

Our paper is organized as follows: in Section 2, we present our lens on the initial conditions of US agricultural policies coming into the 2006-12 period. We assess the impacts of these earlier policies on basic food commodity markets in the United States and their spillover effects on world markets. In Section 3, we turn to the evolution of US biofuel policies and investigate their effects on commodity prices and price volatility, as well as their interactions with the policies of other countries. In Section 4, we analyse the political economy of these policies, the changing US political landscape, and the current Farm (or Food) Bill politics that are linked to biofuels. Finally, Section 5 offers concluding remarks.

\footnotetext{
${ }^{2}$ We focus on the United States, the European Union, and Brazil because the United States accounts for 42 per cent, Brazil for 24 per cent, and the European Union for 14 per cent of total 2012 world biofuel production.

3 Many papers in the literature have noted the influence of biofuels on commodity prices. For excellent surveys of this literature, see Abbott, Hurt and Tyner (2008), Hochman et al. (2011), and Zilberman et al. (2012).
} 


\section{Historical US food and agricultural policies}

Throughout most of the twentieth century, the inelastic demand for agricultural commodities, combined with growing productivity, helped depress agricultural prices (Cochrane 1993). Beginning in the 1930s, US agricultural sector policies focused on controlling supplies of programme commodities in order to increase market prices and, ultimately, net farm income. Over the years, this governmental effort to relieve the pressures of excess supply generated a host of unintended consequences: periods of large public stockholding, over-allocation of variable input resources, and depressing effects on world food commodity prices. The US government also attempted to expand food demand, via the foreign food aid programme, the domestic food stamp programme, export subsidies, and the USDA's Foreign Agricultural Service export enhancement programmes. The voluntary nature of the governmental programmes allowed participants to gain access to governmental subsidies so long as various supply control mechanisms (such as crop acreage-base restrictions, annual acreage-idling programmes, and conservation programmes) were honoured.

Since 1985, the Farm Bill legislation that defines US agricultural policy has slowly been transformed into a 'food bill.' The Food Security Act of 1985 included programme commodity provisions that focused on loan programmes, target prices, deficiency payments, acreage reduction, and public grain stock reserves. Export provisions in this legislation included food aid and cargo preferences. Conservation provisions created 'sod buster,' 'swamp buster,' and conservation reserve programmes, with the stated intent of removing highly erodible land and wetlands from production and thus, indirectly, managing supply response (Rausser 1992). This Act also authorized three alternative market promotion programmes and continued food stamp programmes. ${ }^{4}$

During the 1980s, for the first time, our profession turned to an empirical investigation of the role of US monetary and fiscal policies relative to US agricultural policies in order to explain the volatility of foodgrain and livestock prices. In the 1970s, the 'overshooting' phenomenon could be traced to the flex-vs.-fixed price dichotomy of Okum (1975) and Dornbusch (1976). In particular, the disequilibrium in money markets caused disequilibrium in commodity storage and exchange rate markets. Sudden USSR grain purchases also had a major impact on prices. These phenomena helped explain the price spikes that had taken place throughout the 1970s (Rausser et al. 1986). In contrast, the disequilibrium in money markets and exchange rate markets ran in the opposite direction during the 1980s, forcing volatility on the downside for a number of food commodity markets. Had it not been for governmental market subsidy programmes, the agricultural financial crisis of the mid-1980s would have been even more dramatic (Rausser et al. 1986; Foster and Rausser 1991).

By the end of the 1990s, it was becoming increasingly clear that the economic wellbeing of the US agricultural sector depended more on access to overseas markets for its products than on the distortions orchestrated by US government policy-making. Accordingly, the flavour of public discourse resulted in a 1990 Farm Bill that aimed to enhance exports. For the first time, the legislation also introduced planning flexibility provisions, which emphasized economic freedom and increasing resource capacity to respond to world market conditions. At the time of the 1990 legislation, while Uruguay Round negotiations were continuing, the

\footnotetext{
4 After this 1985 legislation was passed, export subsidies from both the European Union and United States created a prisoner-dilemma global competition, with the net effect of decreasing world food commodity prices (Economic Report of the President 1987).
} 
empirical evidence that coupled subsidy policies were depressing market prices was undeniable (Economic Report of the President 1987; Rausser 1995).

After the Uruguay Round concluded, the 1996 Farm Bill (the Federal Agriculture Improvement and Reform Act) replaced the previous target price deficiency payments with fixed 'production flexibility contract payments' over the course of seven years. Both the crop basis and the acreage reduction programmes were eliminated. For the first time, farmers participating in US government programmes were allowed to make their own planning decisions, free of government regulations (with minor restrictions). In the political economic process that influenced this legislation, various commodity organizations and agribusiness interests coalesced, in the hope that a more market-oriented agricultural policy would develop. Many in our profession hoped that these seven-year production flexibility payments would allow the US government to terminate gracefully the institutional vehicles for commodity market subsidization. However, political economic forces squelched this hope with the passage in 2002 of the Farm Security and Rural Investment Act. Over a six-year period, this new Act budgeted almost US $\$ 40$ billion for commodity programmes and almost another US\$10 billion for conservation.

In the movement from legislation that had focused largely on agriculture to legislation focusing on food consumption, more than 50 per cent of the allocations made in the 2002 Act (US\$149.6 billion) were directed to food stamps and other nutrition title programmes. This trend accelerated with the passage of the 2008 Food, Conservation, and Energy Act. In this most recently implemented legislation, 'nutrition' subsidies accounted for more than 75 per cent of the outlays for authorized programmes. The total budget authority over five years for this act amounted to US\$284 billion (Congressional Budget Office 2008).

In the current century, the United States-and the world-has shifted from chronic excess supply (due to greater growth in farm productivity than in demand) ${ }^{5}$ to chronic excess demand and rising real food prices. Together, slower annual percentage rates of increase in agricultural productivity and rising increases in farm commodity demand from China and from energy producers precipitated a complementary shift in US farm commodity policy from suppressing to stimulating supply of farm output. Moreover, the United States' agricultural sector has become, on average, more prosperous relative to the rest of the economy, so that the distributional justification for many agricultural policies in the United States has ceased to exist (Gardner 1992). In this sense, continued agricultural subsidies were rewarding rentseeking and political muscle. As the agricultural industry realized the value of developing new sources of demand for agricultural commodity that has a higher price elasticity, biofuels became increasingly attractive.

\footnotetext{
5 As de Gorter, Nielson and Rausser (1992) formally demonstrate, the complementarity between public good research and development and commodity-based subsidization helps explain the huge productivity increases in food commodity production in the United States (along with coupled-subsidy policy). The federal and state support of land grant universities and public good research and development, along with the support of cooperative extensions, has been instrumental in expanding supply response to both market-based and government-based incentives. This joint complementarity between public good research and development and commodity subsidization has been theoretically demonstrated on numerous occasions (Innes and Rausser 1989; Foster and Rausser 1993; Rausser and Foster 1990). Everything else constant, the complementarity of these two policies has reduced what would otherwise have been greater price volatility as well as depressed what would otherwise have been higher price levels.
} 
It is not surprising, then, that the most recent agricultural policy legislation includes energy. Although the 2008 Act explicitly budgeted only a small amount for energy expenditures (approximately US\$643 million over a five-year period under Title IX), when combined with US renewable energy legislation, ${ }^{6}$ the increased legislative support for US biofuel policies becomes evident. One of the major economic motives for the renewable energy legislationand for resulting US biofuel policies-was that they led to increases in prices of corn, oilseeds, and wheat as feedstocks. A second motive was the widespread political desire to reduce highly visible programme commodity subsidies (e.g., deficiency payments). Such legislation and the policies it spawned have led to increased demand for corn, oilseeds, and wheat as feedstocks for biofuel production: between 2003 and 2012, US ethanol production increased sevenfold. Meanwhile, EU biodiesel production also increased sevenfold, and Brazilian ethanol production increased threefold.

\section{The evolution of US biofuel policies}

The political economic landscape underlying US biofuel policies has been shaped by a broad spectrum of energy-, agricultural-, and environmental-policy objectives. Here, we focus on energy security, farm policy, and environmental goals.

\section{Energy security goals}

The US government first implemented tax credits for ethanol fuel blenders and import tariffs for foreign ethanol producers in 1978 and 1980, respectively. Proponents justified these measures by citing the need to improve energy security and to counter oil supply disruptions such as those that had occurred in the 1970s. The tax credits and tariffs were designed to reduce dependence on oil in order to address rising public concern about dwindling oil supplies and rising and unstable oil prices. In particular, proponents of these measures sought to reduce dependence on imported oil (and other imported sources of energy, including ethanol), especially oil imported from unstable governments in the Middle East. Energy security policy aimed to diversify energy supplies. Two final objectives were to conserve foreign exchange earnings and to create valuable domestic 'green jobs'.

A hitch arose when the IRS insisted that compliance with GATT rules meant that the ethanol tax credits must be made available to providers of imported as well as domestic ethanol. In response, the US Congress set a special import tariff ('special taxes and charges') of \$0.54 per gallon on imported ethanol in order to offset the ethanol importers' tax credit. ${ }^{7}$ Plainly, 'energy security' does not fully explain such measures as the tariff on imported ethanol, since Brazilian ethanol would have been just as effective (or more effective, given its potentially lower price) in reducing US dependence on oil. In much public discourse, the term energy security functioned as a loosely defined slogan that provided cover to lobbyists and entrepreneurial politicians seeking new and continued government policy interventions that would serve their self-interests.

\footnotetext{
6 Although the Renewable Fuel Standard (RFS) was not enacted until 2005, bills containing variants of the RFS were repeatedly debated by the US Congress (in 1978, 1987, 1992, 2000, 2001, 2003, and 2004). All were strongly supported by the corn lobby. These lobbying efforts led the RFS for corn ethanol to be doubled in 2007. The 2007 RFS specifies minimum renewable fuel production each calendar year from 2007 through 2022: the 2022 standard is four times that of 2008.

7 This special tariff was scheduled in the Uruguay Round tariff tables and passed without objection.
} 


\section{Farm policy goals}

After oil prices declined in the mid-1980s, the farm lobby continued to use ethanol policy for its own purposes. The farm lobby claimed that fostering ethanol production via mandates, tariffs, and tax credits would help achieve farm policy goals by improving farm incomes and promoting rural development. In the meantime, the higher prices farmers received for their crops (especially corn) meant lower costs to taxpayers of price contingent government farm subsidies. However, the complex links among biofuel policies, farm income, and rural development produce novel effects. For example, an implicit tax on value added agriculture (such as the livestock, dairy, and poultry sectors), in the form of higher prices for corn and other feedstocks, can reduce the incomes of these farmers. This result would ultimately defeat the same US farm policy goals that supposedly justify ethanol support. Ethanol support measures can also constrain economic growth in rural areas, even if biofuel production brings in increased revenue for some rural farmers or processors. Since ethanol production is capital-intensive, its primary effect on rural development is to increase land prices, which is unlikely to benefit many farmers.

In current debates over biofuel policies, proponents of subsidies and tax credits sweep aside the fact that biofuel policies affect the level at which loan rates and target prices are set. Higher corn prices (and prices for related crops) give politicians an incentive to increase price supports more than would be the case if no biofuel policies existed and crop prices were lower. As a result, taxpayers must shoulder burgeoning costs. For example, the 2008 Farm Bill increased support prices for 14 of the 28 crops listed. As a result, high crop prices caused governmental crop insurance payments to farmers to escalate. When these feedback loops are ignored, estimates of the effects of biofuel policy become woefully inaccurate (de Gorter and Just 2009a).

\section{Environmental policy goals}

Environmental policy goals were first formulated in the United States in the Clean Air Act regulations of the 1990s. The initial impetus for environmental policy goals was to improve local air quality and to replace MTBE as a gasoline oxygenator with ethanol (MTBE leaking from underground storage tanks was found to contaminate local water supplies, Rausser et al. 2004). The MTBE controversy gained traction slowly but came to a head in 2005, when federal courts refused to grant immunity to companies facing lawsuits over MTBE contamination. MTBE's demise as a gasoline oxygenator then triggered a huge jump in ethanol prices.

More recently, concern among the American public about greenhouse gas emissions has prompted more vigorous efforts to strengthen environmental policy. However, protecting the environment became a political driver in Washington only after energy security concerns and farm policy goals had been articulated. In contrast to the European Union, where concern about greenhouse gas emissions has been one motivation for energy policy for several years, US policy makers have, in general, become motivated only very recently to advocate measures that will reduce greenhouse gas emissions. Moreover, corn producers' lobbying groups were one of the first groups to promote biofuels based on projected greenhouse gas reductions. 


\subsection{Types of US biofuel policies and their effects on grain prices}

The US biofuel policies that were implemented during the period 2006-12 include the following: ${ }^{8}$

- biofuel consumption subsidies, such as the tax credits (implemented in 1978) that expired at the end of 2011;

- formal ethanol mandates such as the Renewable Fuel Standard, which took effect in 2005 (and was revised upwards in 2007); ${ }^{9}$

- $\quad$ de facto mandates that ethanol be used in fuel to satisfy environmental regulations, such as provisions of the Clean Air Act in the 1990s resulting from the banning of MTBE;

- $\quad$ production subsidies for both biofuels and feedstocks; ${ }^{10}$

- $\quad$ import tariffs and tariff rate quotas, such as the US $\$ 0.54 /$ gal ethanol import tariff (implemented in 1980) that expired at the end of 2011; and

- $\quad 0,1$ sustainability standards: the standard that one gallon (energy equivalent) of corn ethanol must reduce greenhouse gas emissions by 20 per cent relative to the gallon of gasoline it is assumed to replace. ${ }^{11}$

Although each type of policy affected corn prices, it did so through various channels at various times and magnitudes. The key to understanding how these biofuel policies affect grain commodity prices is to recognize the links between ethanol prices and corn prices: ${ }^{12}$ ethanol prices are indirectly linked to gasoline prices (through mandated premiums above the tax credit), and gasoline prices are a direct function of oil prices. ${ }^{13}$ The corn ethanol price transmission elasticity (see Section 3.3) is the key driver for corn prices (de Gorter and Just 2008), and hence, as we will show later, for all grain prices. ${ }^{14}$

${ }^{8}$ Many of the federal incentives, subsidies, and mandates listed here have been complemented by similar state measures.

9 There are four major categories of the first two types of biofuel policy, tax credits and mandates: ethanol, biodiesel, advanced biofuels, and advanced cellulosic biofuels. Biodiesel (mostly from soybean oil but also from other oilseeds, with about 20 per cent of the total coming from recycled vegetable oils and animal fats) and sugarcane ethanol qualify for the advanced biofuel mandate because they meet the 60 per cent greenhouse gas reduction threshold. In contrast, crop biomass is not eligible for the cellulosic mandate (in order to qualify for the cellulosic mandate, raw material must be composed primarily of cellulose). Brazilian sugarcane ethanol does meet the cellulosic ethanol mandate's 60 per cent greenhouse gas reduction requirement.

${ }^{10}$ In addition to direct production subsidies for biofuels, many federal and state 'infrastructure' subsidies were created, such as subsidies for alternative vehicles and fuelling stations.

${ }^{11}$ It is ' 0,1 ' in that if greenhouse gas emissions for corn production are below the threshold, ethanol is not eligible for tax credits or to be counted toward the mandate.

12 This price link must be adjusted for ethanol production subsidies.

13 An indirect link between oil and corn prices always exists through input costs, since corn uses energyintensive inputs. This factor has been characterized as a major driver of commodity price increases. See, e.g., Baffes and Haniotis (2010) and Abbott, Hurt and Tyner (2008).

14 The links between rapeseed, soybean, and palm oil prices and biodiesel prices, and between biodiesel and diesel gasoline prices, are equally important, as is the link between sugarcane, sugar, and ethanol prices in 


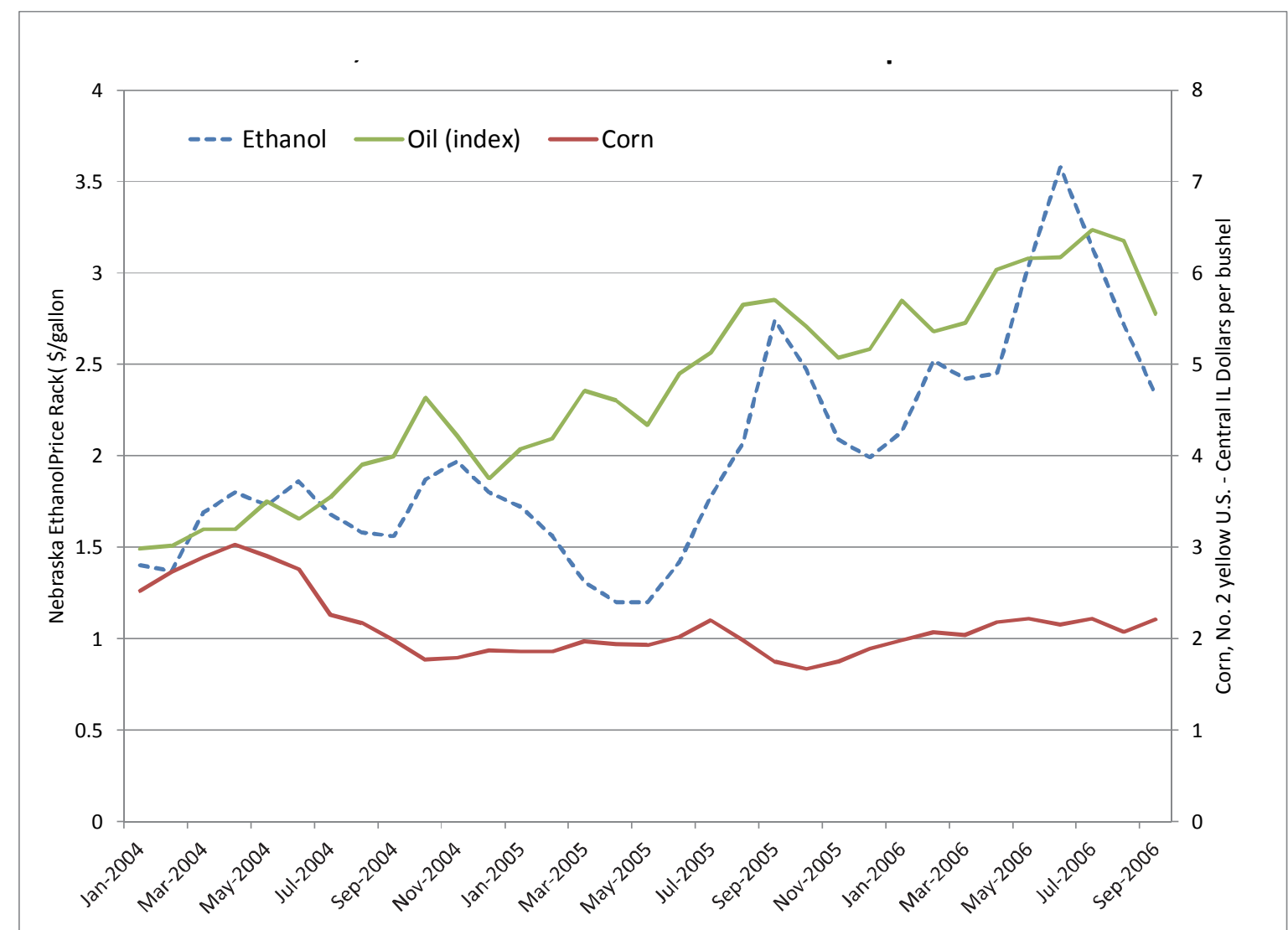

Corn price = No 2 yellow US - Central IL \$/bushel (available at: www.ers.usda.gov/data-products/feed-grainsdatabase/feed-grains-yearbook-tables.aspx )

Ethanol price $=$ Nebraska rack \$/gallon (available at: www.neo.ne.gov/statshtml/66.html)

Oil price $=$ World Bank Pink Sheets (available at: www.econ.worldbank.org/WBSITE/EXTERNAL /EXTDEC/EXTDECPROSPECTS/0,,contentMDK:21574907 menuPK:7859231 pagePK:64165401 piPK:64165 026 theSitePK:476883,00.html)

Ethanol capacity and under construction (million gallons) (Renewable Fuel Association) (available at: www.ethanolrfa.org/pages/statistics\#C)

Source: Authors' computation, based on data as given above.

US biofuel policy began to noticeably affect foodgrain commodity prices in October 2006. Until that date, as Figure 1 reveals, corn prices held steady even though oil prices steadily increased (and even crossed the US\$40/barrel threshold in mid-2004). ${ }^{15}$ Since the products that initially competed with ethanol as gasoline additives (oxygenated and octane enhancers, particularly MTBE) were petroleum-based, ethanol prices followed crude oil-derivative gasoline prices (Figure 1). As one state after another banned MTBE, continued upward pressure was exerted on ethanol prices. When a federal court failed to grant immunity against lawsuits for firms using MTBE in July 2006, ethanol prices reached their all-time highs. Until that date, corn markets were relatively stable (Figure 2a), even though rising ethanol prices were leading ethanol plant capacity to escalate (Figure $2 b$ ). ${ }^{16}$

Brazil. Note that ethanol production creates a large distillers' grain market, which, owing to the high protein content, serves to displace soybean meal consumption and drive down soybean price and production.

15 In the 2005-06 crop year, the US farm price of corn averaged only US\$2/bu, even though world commodity trade had been increasing sharply for years, following the fastest-ever growth of emerging economies.

16 As Carter, Rausser and Smith (2012) show, by mid-2006, corn stockholding was beginning to expand in anticipation of demand from ethanol plants. 
Figure 2a: Corn prices catching up to ethanol production capacity

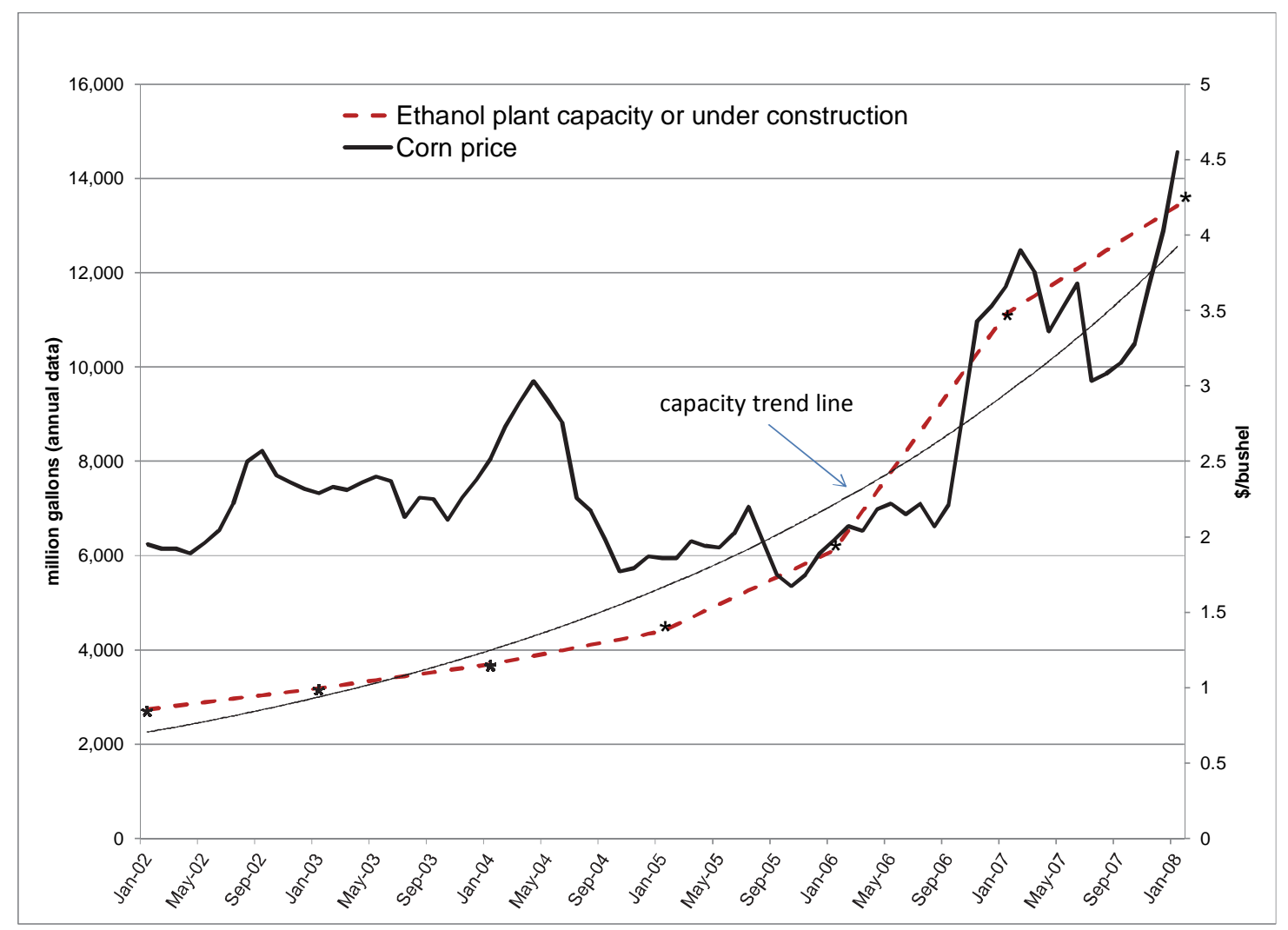

Figure $2 \mathrm{~b}$ : Ethanol prices leading ethanol production capacity

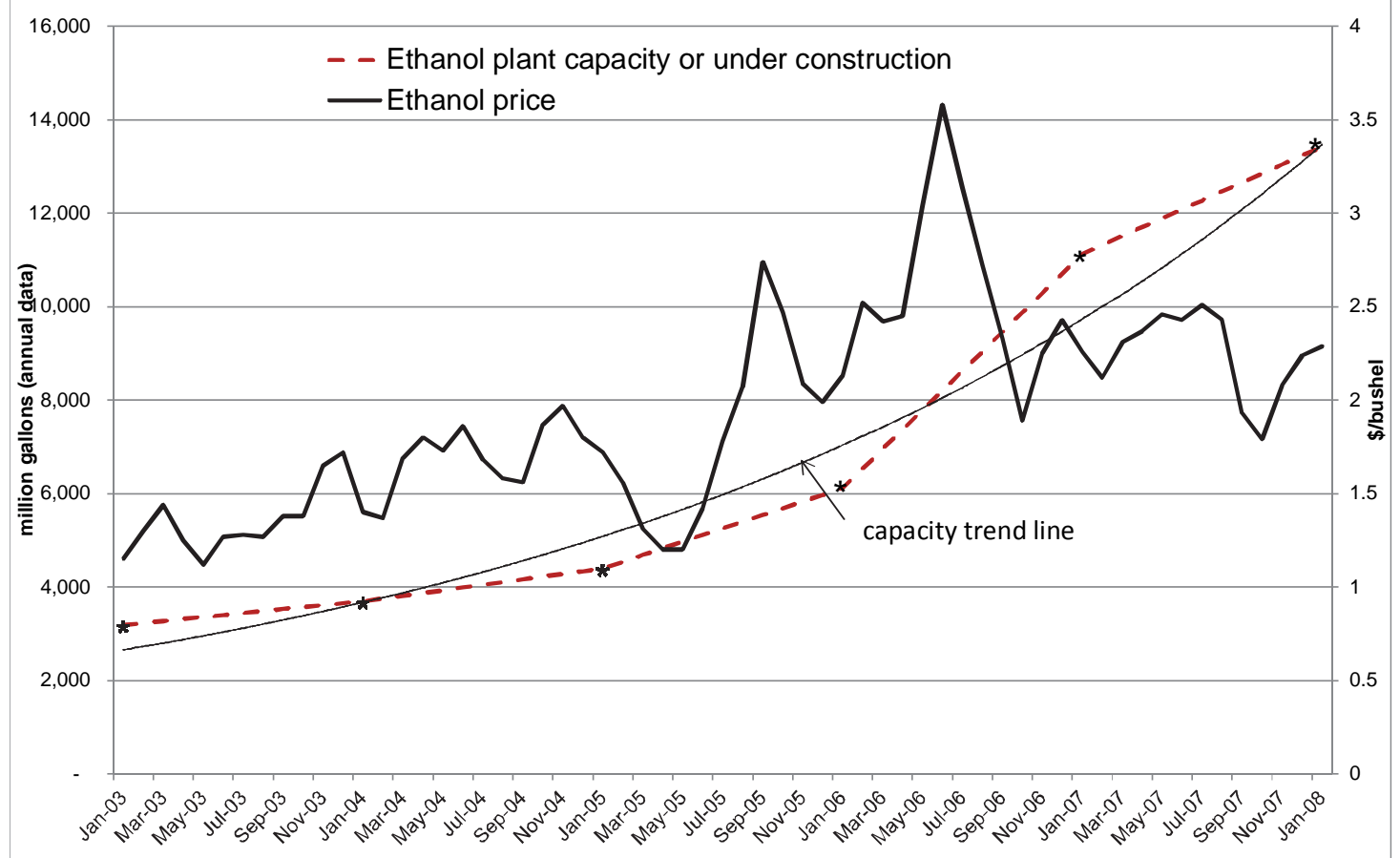

Source: As given in Figure 1. 
Beginning in October 2006, the corn price finally reacted to higher oil and ethanol prices. ${ }^{17}$ Coupled with the de facto ban on MTBE, high oil prices activated the otherwise dormant ethanol blenders' tax credit by providing a premium on ethanol over gasoline prices. Ethanol prices soared to a peak of US\$3.65/gal in July of 2006 (Figure 1). ${ }^{18}$ By September 2007, corn and ethanol prices had become tightly linked (Figure 3), and corn ethanol markets reached equilibrium. Between October 2006 and September 2007, markets were in adjustment, from the disequilibrium situation depicted in Figure 1 to the equilibrium linking corn to ethanol prices.

Meanwhile, soybean prices (in the United States) and rapeseed oil prices (in the European Union) became tightly linked to biodiesel prices. Like corn ethanol production, non-corn ethanol biodiesel production also affects prices. Although the volume of total biofuels production in OECD countries (excluding US corn ethanol) is only half that of US ethanol production, this non-US OECD biodiesel production requires much more land area per gallon of biofuel yielded (e.g., wheat for ethanol or rapeseed and soybeans for biodiesel). As a result, non-corn ethanol biodiesel production has a disproportionate impact on foodgrain

Figure 3: US corn and ethanol prices

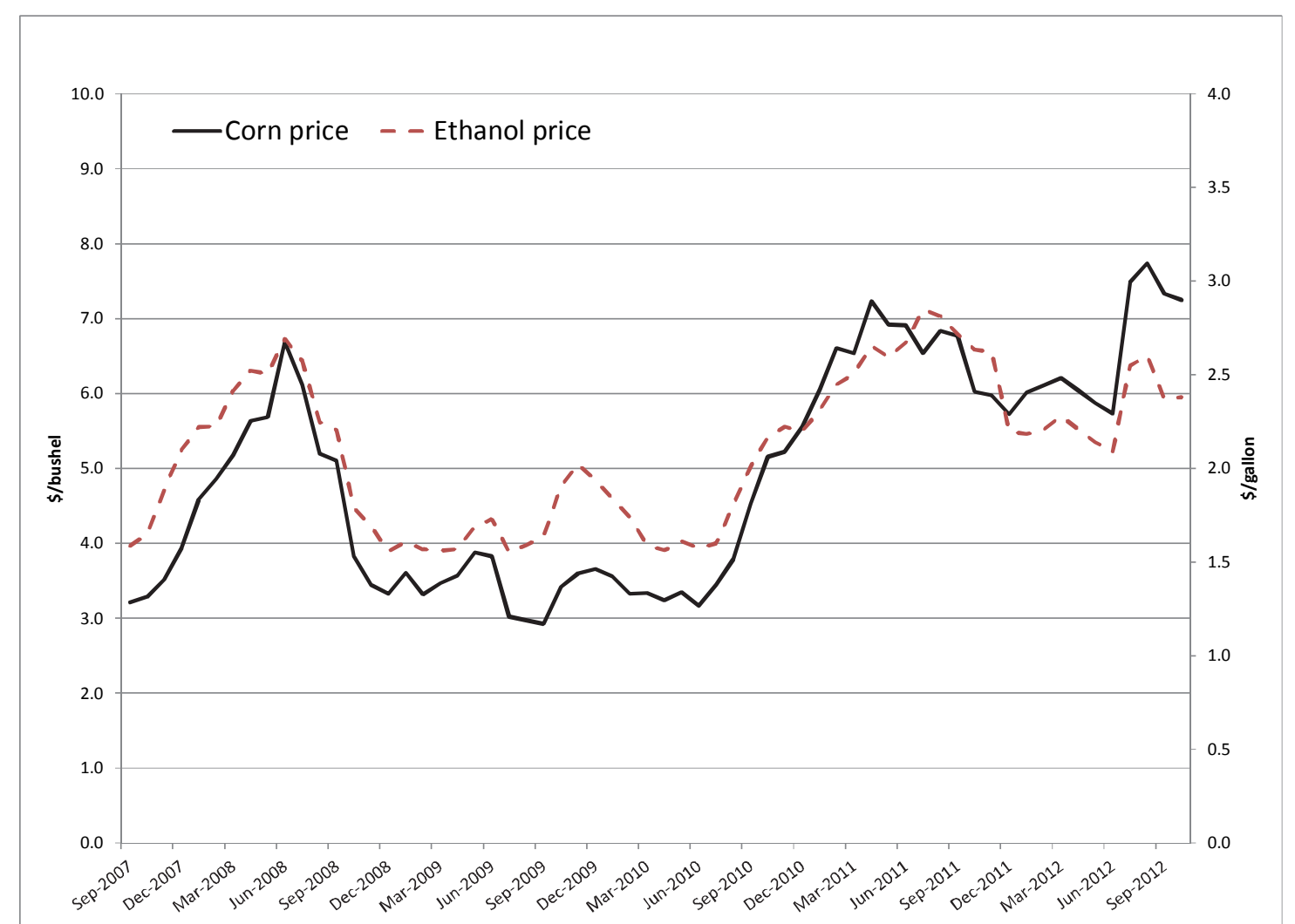

Source: Authors' computation, based on corn price lowa farm \$/bushel and ethanol price lowa \$/gallon, data sourced from: CARD, lowa State University (available at: www.card.iastate.edu/research /bio/tools/hist_eth_gm.aspx).

17 Enders and Holt (2012) determine a structural break in corn prices for October 2006 using sophisticated econometric techniques, confirming our analysis in Figures 1 and $2 \mathrm{a}$ and 2b that October 2006 was an important month.

18 Ethanol prices have never regained this peak. As of this writing (April 2012), the ethanol price is US\$2.12/gal. Meanwhile, the recent oil prices were close to their all-time monthly average high of US\$133/barrel (June 2008). 
prices. Because soybean and corn are largely substitutable on land in the United States, and because prices among alternative oilseeds are directly linked because of very high substitution in demand, any change in land use for biodiesel production will have one-to-one impacts on oilseed and corn prices (and vice versa for corn ethanol production on oilseed prices). Owing to competition for land and substitutability in demand, we would expect wheat to be tightly linked to both corn (and coarse grains in general) and oilseed prices. In contrast, we would expect the rice price to be less closely related to coarse grain and oilseed prices in the short run, since there is no need for the rice price (in contrast to corn and oilseed prices) to respond to crude oil prices (and hence corn and oilseed prices).

The environmental and renewable energy policies of the United States, in combination with those of other OECD countries, have evidently also been critically important in establishing the link between foodgrain commodity prices and biofuel prices (Tyner 2008) and for supporting the surge not only in corn, oilseeds, and other coarse grain prices but also in wheat and rice prices during 2006-08. As oil prices dropped in 2008-09, biofuel policy moderated the ensuing decline in foodgrain commodity prices. Ever increasing biofuel price premiums over gasoline and diesel prices and the subsequent rise in oil prices in 2011 resulted in alltime high prices for corn and other grains and oilseeds.

\subsection{A domino effect}

Once corn and oilseed prices had become more closely linked to crude oil prices through ethanol and gasoline markets, and crude oil prices had increased, corn and soybean prices inevitably followed suit. In contrast, although wheat is used for ethanol production in Canada and Europe, there is no evidence that wheat prices follow ethanol prices. Nonetheless, wheat is related to other grains because of competition for land and demand substitution as well as other external events (such as monetary policy and exchange rates). Like wheat prices, rice prices are not directly linked to biofuels, but in India, rice competes for land with wheat, and in many parts of the world, rice is substitutable in demand for both wheat and corn. It is therefore not surprising that all four price categories (coarse grains, oilseeds, wheat, and rice) rose to their peaks in mid-2008, at about the same time when crude oil prices peaked (Figures 4, 5, and 6). Similarly, prices for all of these commodities rose again in 2010.

The month of October, 2006, when corn prices increased, is pivotal to understanding this domino effect. The central Illinois farm price for corn increased 88 per cent between August 2006 and February 2007 (Kansas City 2 No. 2 white corn prices increased 107 per cent in the same time period). Although world wheat production was down by 3.9 per cent in 2007, overall grain production was essentially unchanged that year. But wheat prices were pulled up by the sudden increase in corn prices (Figure 4). India and Ukraine's export bans on wheat occurred immediately after corn prices finally reacted to high oil prices and skyrocketed to their interim peak in February 2007. Immediately following these two wheat export bans, increases in the price of wheat (which had risen about US\$3/bu since January 2005) actually overtook the corn price increase. Wheat price increases began the last leg of their ascent (basically straight up) after the October 2007 rice export ban by India, moving from US\$7 to US $\$ 11 /$ bu in a very short period. Wheat prices peaked before corn prices and also began to come down before corn did (although wheat prices blipped up again two months before corn's price peak, while corn prices were still rising). But wheat prices declined again one month before corn prices did and continued their slide for months. 
Figure 4: Corn-wheat price developments

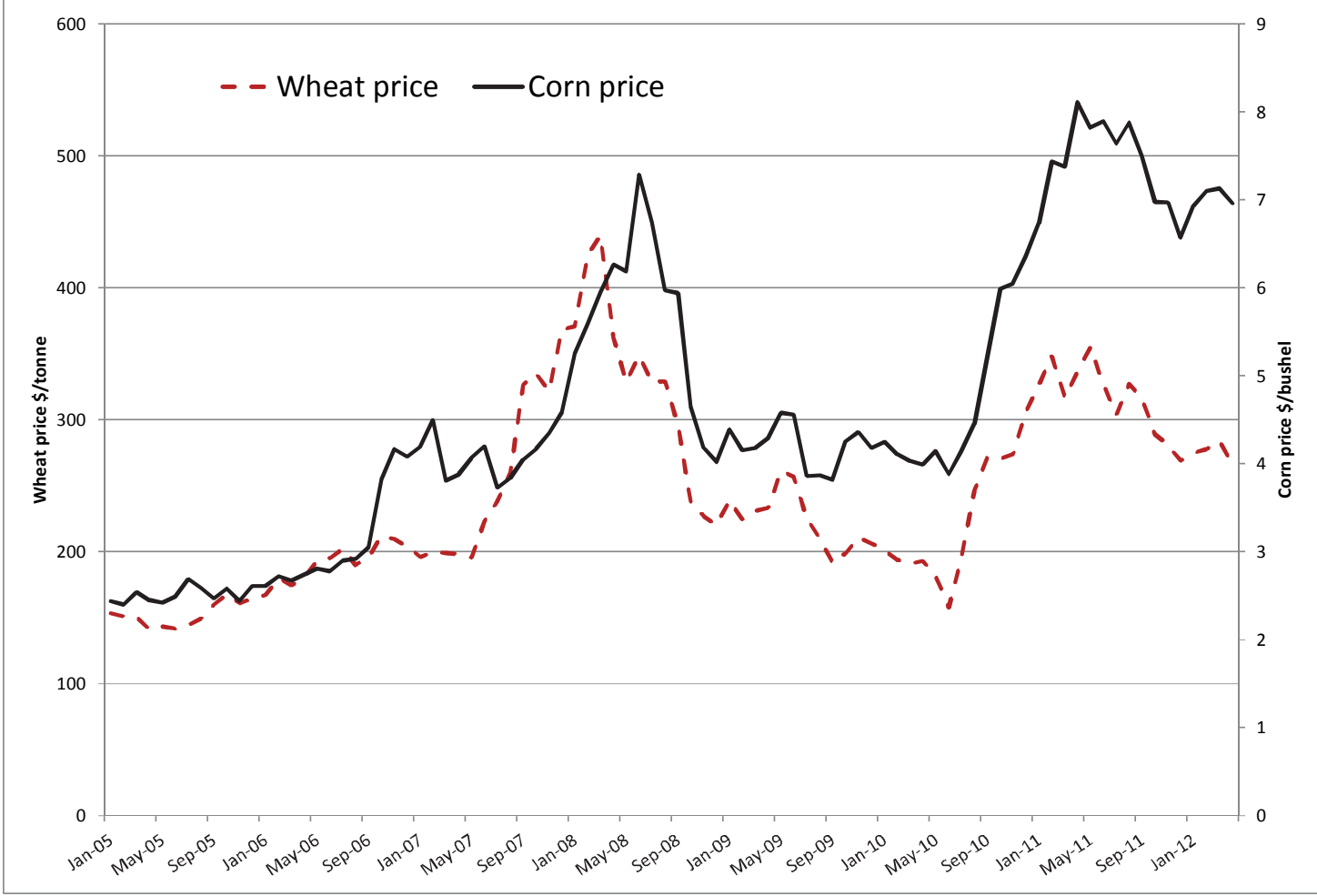

Note: Wheat price $=\$$ /tonne $[(\mathrm{US})$, no. 1 , hard red winter, ordinary protein, export price delivered at the US Gulf port for prompt or 30 days shipment]

Corn price $=\$$ /bushel [Maize (US), no. 2, yellow, f.o.b. US Gulf ports] (Figures 5 and 6)

Rice price $=$ Rice $[($ Thailand), 100\% broken, A.1 Super, government standard, f.o.b. Bangkok]

Source: Computations by authors, based on data from: World Bank Pink Sheets (available at: www. econ.worldbank.org/WBSITE/EXTERNAL/EXTDEC/EXTDECPROSPECTS/0,,contentMDK:21574907 menuPK:7 859231 pagePK:64165401 piPK:64165026 theSitePK:476883,00.html)

Thus, biofuel policies and corn markets started a ball rolling that spilled over into the wheat market and subsequently into the political decisionmaking of Asian governments. Their policy responses set off speculation, including hoarding, which caused rice prices to spike. ${ }^{19}$ As Figure 3 shows, once corn prices were finally linked to ethanol prices (August 2007), corn (and oilseed) prices began to follow oil prices. Contrary evidence in the literature (Zilberman et al. 2012; Serra 2012) on these links between the ethanol, energy, and corn price is largely based on reduced-form timeseries analysis. But our analysis shows that although these links were not visible prior to October 2006 (and remained in flux for nearly another year), beginning in September 2007, ethanol and corn prices did begin move in the same direction month after month. As a result, any timeseries analysis that begins well before 2006 and ends in either 2007 or 2008 misses some key episodes in the development of links between biofuel policies, corn (and oilseed) prices, and energy prices. (It should also be noted that ethanol

19 No major supply or demand shocks occurred at this time in the rice market: 'Rice market fundamentals were not the cause. . . . The rice crisis was not caused by adverse shocks to rice production or low rice stocks. ... The world rice to stock ratio was roughly constant in the three years preceding the crisis. . . World rice trade in the first four months of 2008 . . . was 20 per cent higher than in the first four months of 2007. The favourable situation as regards production, stocks and trade strongly suggests factors other than basic market fundamentals were at work ...' (Dawe and Slayton 2010). 
prices can float above and away from gasoline [oil] prices when mandates become binding and temporarily de-link corn and oil prices.)

Figure 5: Wheat-rice price development

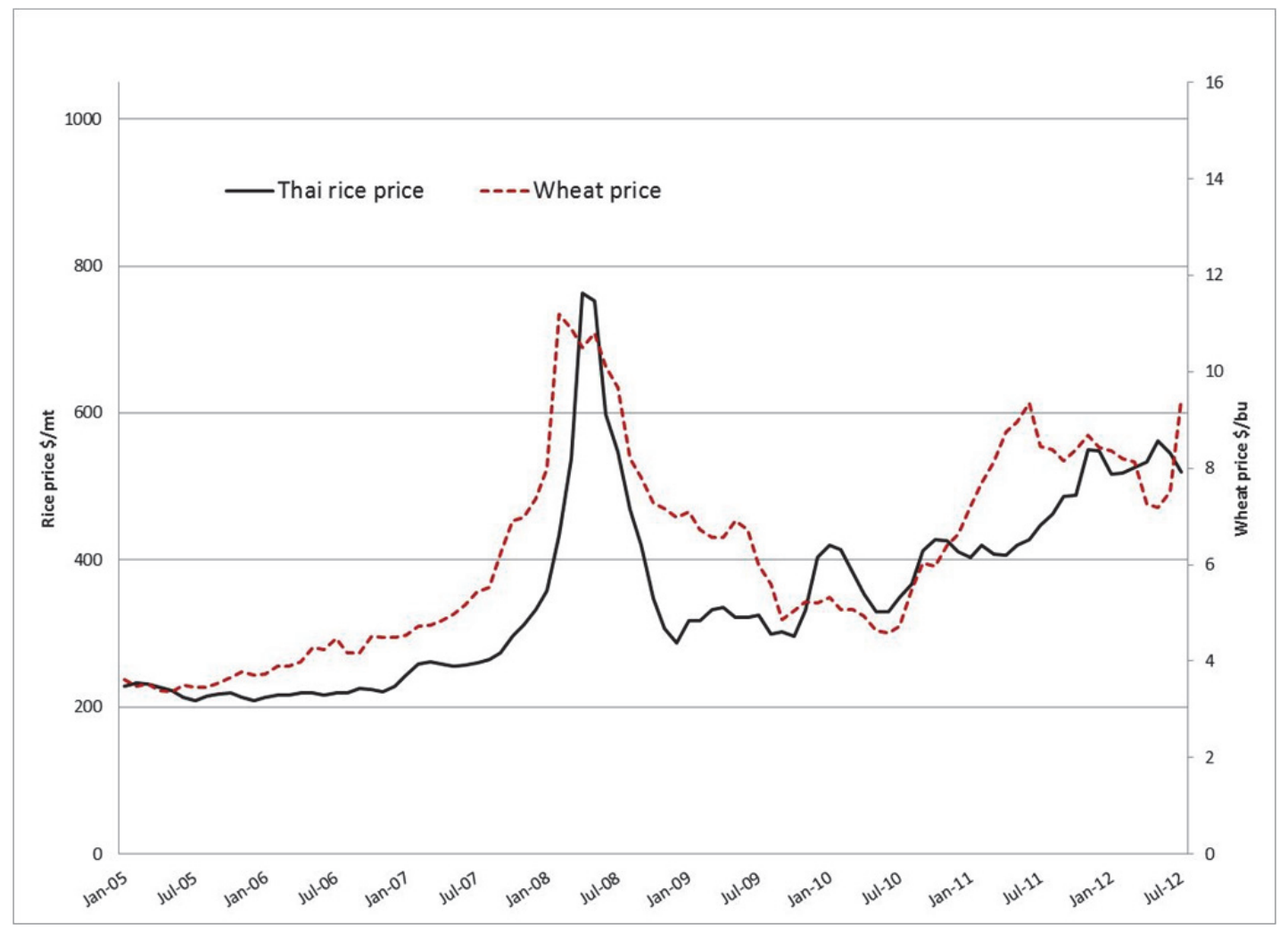

Figure 6: Rice-corn price development

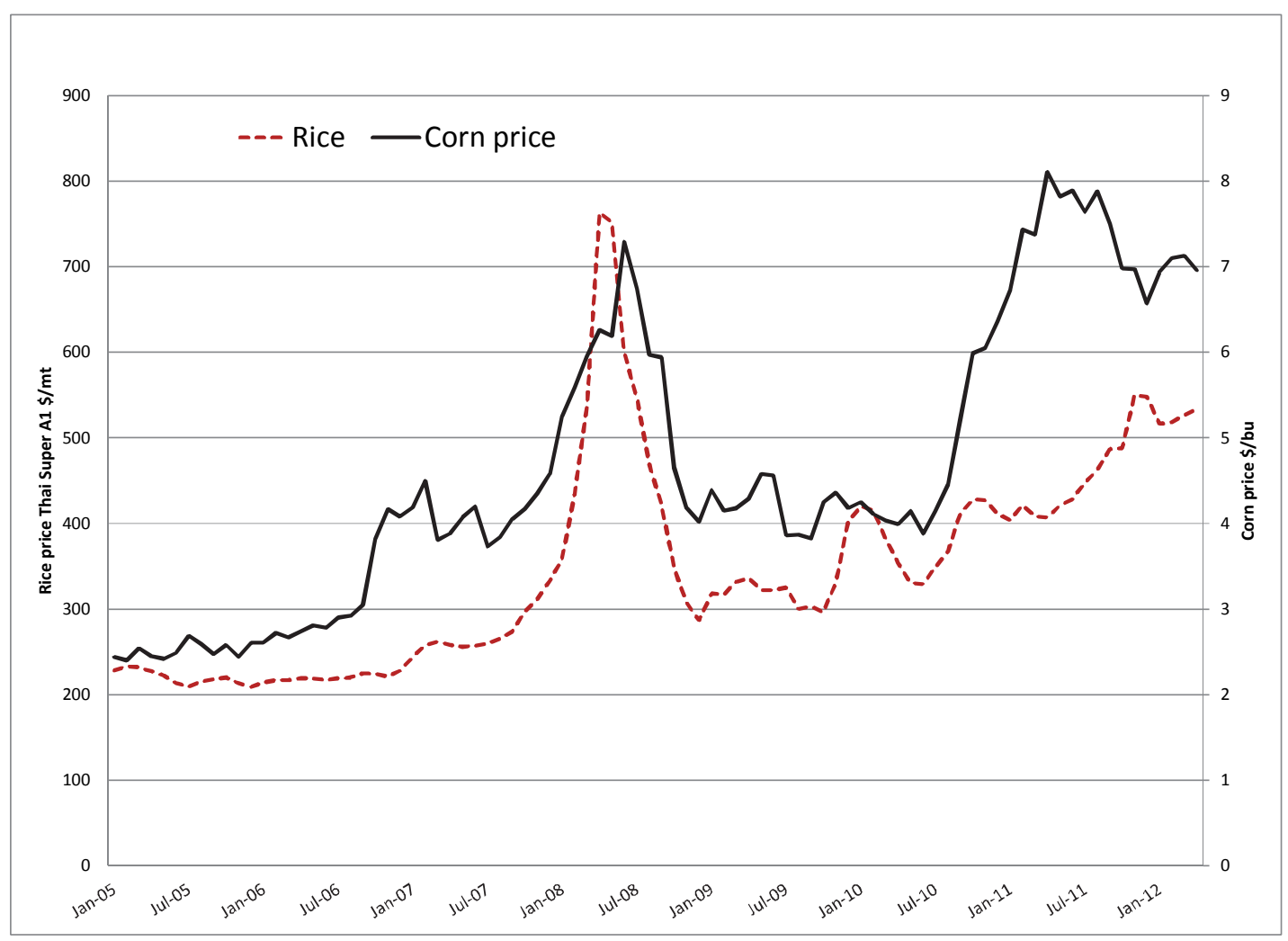

Note and source for Figures 5 and 6: As given in Figure 4.

13 


\subsection{The corn ethanol price transmission coefficient ${ }^{20}$}

The global corn price increases approximately US $\$ 0.04$ per bushel for every US $\$ 0.01$ increase in the ethanol price (Drabik 2011). ${ }^{21}$ Since January 2007, the ethanol price has exceeded the 'no policy' ethanol price, on average, by US\$0.65/gal (ibid.). As previously explained, this difference equals more than the value of the tax credit. The corn ethanol price transmission coefficient was estimated to be 3.85 in 2010 (ibid.). Multiplying 3.85 by the US $\$ 0.65 /$ gal ethanol price premium would imply a corn price increase of US $\$ 2.50 / \mathrm{bu}$, on average. This is not expected, because part of the ethanol price premium is redundant: the intercept of the ethanol supply curve is above the free market ethanol price (for an explanation, see de Gorter and Just 2008). Nonetheless, for 2010, the corn price has been estimated to have been 45 per cent higher than it would have been had the various US ethanol policies not been enacted (Drabik 2011). ${ }^{22}$ But even this figure is an underestimate, because the supply and demand curves that Drabik (2011) calibrated for corn ignore the effects of US biodiesel and biofuel policies on the rest of the world. These other biofuel policies continue to drive corn prices higher: US biodiesel policy, for example, causes farmland to be reallocated from corn to soybeans, increasing the 'no ethanol' corn price. Since other biofuel policies (including those in the rest of the world) have caused the counterfactual corn price (i.e., the price assuming no effect from US ethanol policy) to be higher than would otherwise have been the case, the Drabik estimate of a 45 per cent increase in corn prices for 2010 does not reflect all of the feedback loops.

\subsection{The interactions of global ethanol policies}

In 2010, the United States not only became a significant net exporter of ethanol but the world's largest ethanol exporter. World ethanol prices in 2010-12 were seemingly determined on the margin in the European Union and Brazil, where ethanol prices were significantly higher than they were in the United States. ${ }^{23}$ Brazil had suspended its import tariff in 2009; meanwhile, the US managed to negotiate an agreement with at least five EU countries that allowed 2.1 per cent denatured ethanol to be classified as a blended fuel. This agreement meant that US exporters only had to pay one-third of the approximately 67 per cent EU import tariff on ethanol. In addition, the US tax credit on ethanol exports to the European Union and Brazil acted as a production subsidy for US ethanol producers, in the form of higher ethanol market prices (de Gorter, Drabik and Just 2011; Kliauga, de Gorter and Just 2011). Indeed, 80 per cent of US ethanol exports received the tax credit for as long as it existed (until well into 2011). However, in December, 2011, two events altered this protection of US ethanol production and exports: the European Union closed the tariff loophole the United States had negotiated with some of the Union's members that had

\footnotetext{
20 For a summary of what the structure of biofuel policy predicts regarding foodgrain commodity prices, see de Gorter and Just (2010b), Drabik (2011), Cui et al. (2011), de Gorter and Drabik (2012b), and Lapan and Moschini (2012).

21 Abbott, Hurt and Tyner (2008) claim that the change in the corn price is 2x the tax credit in \$/gal rather than approximately 4x, as Drabik (2011) shows.

22 For an alternative structural explanation, focusing on stockholding behaviour, that generates similar results, see Carter, Rausser and Smith (2012).

23 After mid-2009, Brazilian ethanol prices surpassed US prices, and they remain higher to this day.
} 
classified ethanol exports as fuel, ${ }^{24}$ and the US ethanol tax credit on all exports expired. These two events combined to cause US ethanol prices to decline sharply.

In Brazil, market developments in the sugarcane and sugar ethanol markets since 2009 have been relatively dramatic (de Gorter, Drabik and Kliauga 2012). Brazil's ethanol production has expanded threefold since 2003, and, as noted above, Brazilian ethanol market prices exceeded US prices from mid-2009 onwards. At the same time, Brazil's peak ethanol consumption of 22.8 billion litres in 2009 declined by 19 per cent in 2011, to about 18.5 billion litres. Meanwhile, gasoline consumption in Brazil has increased 24 per cent since 2008. Brazil's ethanol exports peaked at 2.4 billion litres in 2008 and have been around one billion litres in the last two years.

Ethanol prices in Brazil have been driven upward by a strong currency and a sugar export demand shock that took place when world sugar prices reached record levels. In addition, a domestic ethanol demand shock has occurred; demand for ethanol as a transportation fuel has increased as incomes have grown and more consumers buy cars, especially flex-fuel cars. Domestic ethanol supply shocks have also occurred: two years of bad weather, longer rotation in sugarcane crop, and some lingering effects of the financial crisis. The Brazilian ethanol mandate (currently, 20 per cent of the gasoline ethanol mixture is required to be anhydrous ethanol), and governmental control of the gasoline price below the world market price have also helped stimulate both gasoline and anhydrous ethanol consumption.

These developments in Brazil strongly affect US and world ethanol prices. Had it not been for these trends, for example, the US ethanol mandate (RFS) might have resulted in much lower US domestic ethanol prices. The key point is that since 2010, developments in grain markets directly affect the sugar market and vice versa. Some commodity markets have now become more closely linked now that US corn prices are linked, through energy markets, to sugar prices and vice versa. ${ }^{25}$

\subsection{The effect of biodiesel policies on commodity markets}

Before the middle of 2010, when the US biodiesel mandate was finally enforced, the impact of the US biodiesel tax credit on commodity markets was influenced by Canadian and EU biodiesel policies (de Gorter, Drabik and Just 2011). US biodiesel production was essentially zero until 2004 and then increased sharply in 2005-08, when US biodiesel exporters became eligible to receive a US\$1/gal tax credit for the biodiesel fuel they exported, even when they simply added small amounts of diesel fuel to much larger amounts of biodiesel ('splash and dash'). ${ }^{26}$ Some of the biodiesel was imported from other countries, such as palm oil from Malaysia. ${ }^{27}$ This tax credit helped raise the US price of biodiesel by making exports to the

\footnotetext{
24 In late 2011, the EU's Customs Code Committee raised the import tariff on such ethanol blends. See http://www.biofuelsdigest.com/bdigest/2011/10/18/eu-boosts-tariffs-to-block-low-cost-us-ethanol/.

25 Even though Mitchell (2008) correctly recognized that for earlier periods Brazilian sugarcane ethanol production did not have an impact on cereal prices that may no longer be the case.

26 'Splash and dash' refers to the practice of mixing a small amount of diesel (as little as 0.1 per cent-hence the term 'splash') into a boatload of biodiesel so that exporters could receive the blender's tax credit of US\$1/gal and then export the mixture to Europe.

27 In 2007 and 2008, all Canadian biodiesel production was exported, triple-dipping with domestic production subsidies, the US tax credit, and then selling in EU markets with high prices due to tax exemptions at the pump.
} 
EU more profitable. It therefore led to increased soybean prices, which, in turn, raised the price of corn, as land was taken out of corn production and put into soybean production.

However, US biodiesel production (and domestic prices) fell sharply in June 2008, when the European Union began to investigate the 'splash and dash' practice. US biodiesel prices and production plunged, because the US tax credit had acted as a biodiesel production subsidy (even though it was actually a consumption subsidy) when biodiesel prices were determined outside the United States (de Gorter, Drabik and Just 2011). Although the US tax credit was still valid, it could no longer keep prices at historical levels. After the European Union instituted anti-dumping and countervailing duties in March 2009, US biodiesel prices stabilized at lower levels than those prior to mid-2008. The US-EU biodiesel price gap, which had widened sharply in 2008, persisted until mid-2010. At that point, however, the US biodiesel mandate was finally enforced. Since mid-2010, US biodiesel prices and production have increased sharply: current prices (April 2012) are just under US\$5/gal, well above what prices would likely be if the only US biodiesel policy were the US\$1/gal tax credit. In fact, the expiration of the biodiesel tax credit at the end of 2011 has had little effect on US biodiesel prices. Currently, domestic prices of US biofuel are not directly linked to world prices. $^{28}$

\subsection{Interaction effects between mandates and subsidies}

The literature on the economics of biofuel policies has generated the important insight that biofuel mandates interact with production, consumption, and input subsidies through mechanisms that sometimes create unexpected results (de Gorter and Just 2010a). For example, when a premium on the ethanol price is greater than a tax credit, both measures are clearly not necessary. Moreover, the tax credit subsidizes fuel consumption, most of which is gasoline (de Gorter and Just 2009b). The tax credit, therefore, is inherently inconsistent with the environmental and energy goals outlined earlier. The same reasoning applies to production subsidies for both biofuels and their feedstock inputs (e.g., corn production subsidies), although the exact economic mechanisms vary (for details, see Drabik 2011).

The literature has emphasized the superiority of mandates over subsidies from a welfare perspective (Lapan and Moschini 2012). Rajagopal and Zilberman (2007) express concern that enforcing mandates will amplify high commodity prices during periods of commodity shortages. They suggest that biofuel mandates should be temporarily suspended under such conditions. This recommendation has been incorporated into laws but not yet implemented. However, Babcock (2012) suggests that even if mandates are temporarily lifted, their impact on corn prices will be very small because oil refiners have already made substantial investments in the technology of using ethanol as an octane enhancer and face serious switching barriers.

\subsection{Biofuel policies, market shocks, and grain price volatility}

The volatility of corn prices, whether caused by corn supply or oil price shocks, depends on whether a tax credit or a mandate is binding (Yano, Blandford and Surry 2010, 2011). When a fuel blender's tax credit is binding, the corn price is directly linked to the oil price. In addition, as we described earlier, for every US\$0.01/gal increase in ethanol prices, corn prices increase almost US\$0.04/bu. Under such a binding tax credit, exogenous shocks to

28 Note that Brazil insulates its biodiesel sector from world markets. 
corn supply or demand sourced with bad weather, exchange rate depreciation, increasing demand for corn in developing countries, and/or the initial levels of stocks in the supply-ofstorage model have no effects on the corn price level or on corn price volatility (unless the change in ethanol production changes the oil price or there is a resulting regime switch to a mandate) (de Gorter and Drabik 2012a). The volatility in the oil price gets translated into corn price volatility when oil prices determine ethanol prices (through the binding tax credit), because under any biofuel policy, ethanol prices influence corn prices (Drabik 2011).

However, if a fuel blend mandate (rather than a tax credit) determines the ethanol market price, corn do prices respond to corn supply and demand shocks. This vulnerability occurs because the blend mandate significantly weakens the link between ethanol and oil prices (de Gorter and Just 2009b). In fact, higher oil prices mean lower corn prices, because fuel consumption generally declines. Given a fixed ethanol blend requirement, ethanol production contracts as well when oil prices rise, with the result that both ethanol and corn prices decline. But a countervailing effect also exists: a higher oil price translates into higher energy costs in corn production and results in higher corn prices (Baffes and Haniotis 2010). The net change in corn prices due to an oil price increase is indeterminate $a$ priori.

Any analysis of corn price volatility must recognize which biofuel policy is operative (e.g., a tax credit/tax exemption or a blend mandate). It must also analyse the volatility that results from switching between mandates and tax credits (an oil price shock could precipitate such a switch) or from interactions between policies across countries. Surely, in a 'but-for' world without tariffs, the United States would likely have been importing ethanol and so tempering any volatility resulting from corn ethanol linkages. ${ }^{29}$

\subsection{Evolutionary assessment of biofuel policies and grain price fluctuations}

It is important to recognize that the first two categories of biofuel policies, tax credits and mandates, do not, by themselves, discriminate against international trade. But other policies do, and the fact that many were in place for over 30 years in the United States explains, in part, why we have observed increasing corn ethanol production in the United States (rather than, for example, import of less expensive sugarcane ethanol from Brazil). Such antiinternational trade policies also contributed to sharp increases in US ethanol production after 2005, so that world foodgrain commodity prices increased more sharply. Furthermore, the gap in distribution of welfare gains and losses between developed and developing countries widened.

Imported sugarcane ethanol from Brazil was unable to supply the ethanol market in the near term around 2005. Brazil needed time and significant investment in order to increase sugarcane production and expand infrastructure to move ethanol to ports. This obstacle led US corn ethanol production to increase sharply as farmers converted land from other uses in order to increase supply immediately. Here, long-term policies had large short-term implications. If no trade discriminatory biofuel policies had existed, more money would likely have been invested in foreign ethanol production. The sugarcane crop in Brazil, for example, would almost certainly have had a higher production base, and more ethanol infrastructure would have been built to supply world sugar and ethanol markets. Likewise, if

29 Developing country policy responses to higher commodity prices in 2008 (caused by US and EU biofuel policies) in the form of export taxes, for example, further exacerbated commodity price volatility (Carter, Rausser and Smith 2011). 
US environmental policies had been implemented more gradually, US biofuels would not have had such a dramatic effect on commodity prices. In this respect, US biofuel policies constitute new episodes in the saga of distortionary agricultural policies that not only cause world price instability but also harm the welfare of consumers in food-importing developing countries.

Thus, while US agricultural and macroeconomic policies have strongly affected foodgrain commodity prices and volatility, so have US environmental and energy policies. The rollercoaster ride in market volatility since the financial crisis of 2008, and the re-emergence of peaks in corn, wheat, and soybean prices in 2011, can be traced to all three forms of intervention: US renewable-energy, environmental, and agricultural policies. An open question remains as to their relative effect on the level and volatility of grain prices compared to crop supply/demand shocks. In 2009-10, however, corn prices would surely have fallen lower than US\$3.21/bu if US renewable energy and biofuel policies had not supported the market.

US agricultural and biofuel policies have not been the sole influences on programme commodities (especially corn, soybeans, and wheat). Heavy-handed US governmental intervention in domestic and global sugar systems has also influenced world corn prices. US import quotas and internal insulated sugar price supports initially depressed world sugar production and prices. This price depression led Brazil to reallocate sugarcane production away from sugar to ethanol markets. Brazilian sugar ethanol production also responded to increases in crude oil prices that have occurred since the mid-1970s. Currently, however, US biofuel policies are helping to stabilize the ethanol market in Brazil that was earlier destabilized by US sugar policy.

\section{The political economy of US farm, energy, and environmental policies}

The major groups that have been promoting biofuel policies include certain growers' associations, fuel transporters, biofuel producers, automakers, some environmentalists, and the energy security community. ${ }^{30}$ Many of these groups continue to support biofuel policies. Even some environmental groups that opposed tax credits and tariffs now seek to retain mandates. However, other groups are coalescing in opposition to mandates, tax credits, and subsidies. Because ethanol policies support feed grain markets through higher prices, other groups, such as livestock, dairy, and poultry producers, are beginning to form organized opposition to continued support for ethanol producers. So are food processors that no longer enjoy the low market prices that traditional agricultural policies supported. One example of these new interest groups is BalancedFoodandFuel.org, whose members include various meat, livestock, poultry and dairy producer associations (Hahn 2008).

\subsection{The link between biofuels and current Farm Bill politics}

As demonstrated earlier, biofuel polices lead to higher commodity prices, with the unintended consequence of increasing governmental expenditures (e.g., for revenue insurance programmes such as Average Crop Revenue Election [ACRE] and Supplemental Revenue

\footnotetext{
30 Members of the energy security community include retired US Army General Wesley Clark, who is affiliated with Growth Energy. Along with the Renewable Fuels Association, Growth Energy lobbies aggressively for policies advantageous to ethanol producers.
} 
Assistance Payments [SURE], crop insurance, and disaster payments). Higher foodgrain prices also alter the politics of reforms to traditional farm policy, as reflected by the 2008 Farm Bill, in which 14 of 28 price supports were increased.

The impact of biofuel policies is also evident in current Congressional debate on the upcoming Farm Bill. For example, in the latest Senate Farm Bill draft, the Direct Payment and Counter Cyclical Payment programmes have been repealed. But the revenue insurance programme (ACRE) has been expanded into a revenue based risk management programme that is designed to complement the federal crop insurance programme. (Maximum payments, however, are now 10 per cent instead of 25 per cent of revenues.) Meanwhile, SURE is being consolidated with disaster payments, and the crop insurance programmes have been consolidated, with some evidence that they may be augmented.

Since farm revenues have generally increased in recent years, recent farm policy has shifted its focus from maintaining long-term farm income to lessening short-term revenue fluctuations (note that the latter arise, in part, from biofuel demand). Corn prices have risen to levels that make it politically infeasible to maintain direct payments for corn, and countercyclical payments will not be triggered. Evidently, Farm Bill advocates believe it is more advantageous to their interests to redesign such price support policies as 'revenue insurance' programmes that will kick in whenever prices vary (and the loan rate serves as a minimum price guarantee).

The 2012 Farm Bill's stated goal is to save about US\$23 billion for taxpayers. Farm commodity payment reductions will ostensibly account for most of these savings. But the projected savings equal only 35 per cent of the current Direct Payment Programme. The new bill also increases food nutrition expenditures, which are the mirror-image of price contingent farm subsidies: if food prices rise and/or the US economy declines, governmental (taxpayers') expenditures will increase as per capita costs for such expenditures-and the number of beneficiaries - increase. On the other hand, the new or existing oppositional groups mentioned earlier (value added agricultural sectors, environmental groups, consumer groups, and others) have also joined the fray, making the final form of the legislation uncertain.

\subsection{Implications for future US biofuel policies}

Current biofuel policies confirm the information and agency problems of modern political theory. This term refers to the claim that politicians and lobby groups deceive voters (or withhold information from 'rationally ignorant voters') because such groups stand to benefit from doing so. ${ }^{31}$ Obfuscation increases politicians' chances of re-election by making it more difficult for voters to accurately assess policies and programmes that may not serve voters' interests and by attracting support from those who benefit from such policies. Voters' ignorance of such policies' concealed costs (such as disguised transfers) enhances the political strength of proactive interest groups. Specifically, current US biofuel policies have yielded concentrated benefits for farmers and ethanol producers to the detriment of domestic and international consumers. The implication of these information and agency problems for biofuel policy is that the multitude of different policy goals and their complex interactions

\footnotetext{
31 'Rationally ignorant voters' prefer to remain ignorant of issues because they believe the cost of learning about them exceeds the potential benefits (Rausser, Swinnen and Zusman 2011).
} 
facilitates this obfuscation — and may even make it inevitable (Johnson and Libecap 2001; Lawrence 2010).

Even if less-distortionary policies are instituted, the political theory of enforcement and commitment problems helps explain why such policies may not be fully implemented. Political economic trades between individuals and groups rely on contracts and promises that are not enforceable. Governments and political candidates may renege on their policy promises, and citizens may renege on their promised votes. Such enforcement and commitment problems explain why biofuel policies can be difficult to reform. These problems also undermine the possibility of reaching efficient cooperative outcomes.

\section{Conclusion}

US macroeconomic and agricultural policies have always played a significant role in grain price levels and volatility. Up until the period that has been the focus of our analysis (200612), even though US agricultural policies often fostered greater world price volatility, they did so largely by depressing world prices. In sharp contrast, more recent US biofuel policies have introduced new causal mechanisms that have elevated not only domestic but also world prices. For some policy regimes, a direct link has been established between grain prices and energy prices. These commodity prices initially rose in 2006-08, then plummeted in 2008-09 alongside lower oil prices, and finally rose again in 2011 almost to their 2008 peak levels.

These effects partly explain why we emphasize the unique role of the US energy and environmental policies that have been enacted during the last six years. These policies, directed toward energy security, farm policy, and environmental goals, have fostered a more direct link between crude oil, ethanol, and grain prices (particularly corn and soybeans). The actual causal links among these policies did not emerge until September 2006, because prior to that date, tax credits were dormant and mandates had not yet been instituted. From October 2006 through August 2007, a period of disequilibrium adjustments unfolded, and finally, a direct link between corn and ethanol prices was established. Subsequent causal links to crude oil markets via the ethanol market have depended on the policy regime: the link to crude oil can be negative (mandates) or positive (tax credits). Accordingly, US policies that directly affect commodity prices have moved beyond the policy instruments emerging from US Farm Bills to include environmental and energy legislation.

Recognizing that the United States has been a dominant ('large country') player in the implementation of biofuel policies, we have also identified strong linkages between biofuel policies in the United States and in other countries. We have presented evidence that the interactions of biofuel policies instituted by the European Union and Brazil established a nexus for supporting price surges not only for corn, oilseeds, and other coarse grains, but also for wheat and rice. Moreover, the temporary agreement between the United States and five EU countries that allowed the US tax credit on ethanol exports to the European Union to take the form of a production subsidy for US ethanol producers had both short- and long-term effects, including some that failed to increase energy efficiency or to decrease global inequalities. Along similar lines, since the middle of 2010, when the US biodiesel mandate was finally enforced, interactions have taken place between US, Canadian, and EU biodiesel policies that have also increased prices and volatility. Finally, in contrast to some other 
countries that responded directly to commodity price spikes and volatility, the United States' responses to such phenomena have been largely inconsequential. ${ }^{32}$

In summary, the organized interest group landscape for US agricultural commodity policy has changed in recent years. It is now in the throes of a potential transformation. The 'iron triangle' that once influenced governmental intervention in programme commodity markets has expanded into an 'iron maze' of environmental, energy and agricultural organized interest groups-not to mention at least three executive branch agencies (the Department of Energy, the USDA and the EPA). Despite-and because of - these developments, it remains to be to be seen whether such changes can lead to more enlightened policies.

\section{References}

Abbott, P., C. Hurt, and W. E. Tyner (2008). 'What's Driving Food Prices?'. Farm Foundation Issue Report. Oak Brook, IL: Farm Foundation (July).

Babcock, B. (2012). 'Updated Assessment of the Drought's Impacts on Crop Prices and Biofuel Production'. CARD Policy Brief 12-PB 8 (August). Available at: www.card.iastate.edu/publications/dbs/pdffiles/12pb8.pdf

Babcock, B. N., and N Paulson (2012). 'Potential Impact of Proposed 2012 Farm Bill Commodity Programmes on Developing Countries’. ICTSD Programme on Agricultural Trade and Sustainable Development, Issue Paper No. 45 (September).

Baffes, J., and T. Haniotis (2010). 'Placing the 2006/08 Commodity Price Boom into Perspective’. WB Policy Research Working Paper 5371. Washington, DC: World Bank.

Carter, C., G. C. Rausser, and A. Smith (2011). 'Commodity Booms and Busts'. Annual Review of Resource Economics, 3: 87-118.

Carter, C., G. C. Rausser, and A. Smith (2012). 'The Effect of the U.S. Ethanol Mandate on Corn Prices'. Unpublished manuscript.

Cochrane, W. W. (1993). Development of American Agriculture: A Historical Analysis, 2nd edn. Minneapolis: University of Minnesota Press.

Congressional Budget Office (2008). Letter from Peter R. Orszag, Director, to Honorable Tom Harkin, Chairman, Committee on Agriculture, Nutrition and Forestry, US Senate (May 13). Available at: www.cbo.gov/sites/default/files/cbofiles/ftpdocs/92xx/doc 9230/hr2419conf.pdf

Cui, J., H. E. Lapan, G. C. Moschini, and J. C. Cooper (2011). 'Welfare Impacts of Alternative Biofuel and Energy Policies'. American Journal of Agricultural Economics, 93(5): 1235-56.

Dawe, D., and T. Slayton (2010). 'The World Rice Market Crisis of 2007-2008'. In D. Dawe (ed.), The Rice Crisis: Markets, Polices and Food Security. London and Washington, DC: Food and Agriculture Organization Rome and Earthscan Publishing.

de Gorter, H., and D. Drabik (2012a). 'Biofuel Policies and Grain Crop Price Volatility'. Biofuels, 3(2): 111-13. Available at: www.future-science.com/toc/bfs/3/2

\footnotetext{
32 An exception was the negotiation by the United States of the release of Japanese rice stocks in 2008 (mentioned in the Introduction).
} 
de Gorter, H., and D. Drabik (2012b). 'The Effect of Biofuel Policies on Food Grain Commodity Prices'. Biofuels, 3(1): 21-4. Available at: www.future-science.com/doi/pdf /10.4155/bfs.11.149

de Gorter, H., and D. R. Just (2008). ' "Water” in the US Ethanol Tax Credit and Mandate: Implications for Rectangular Deadweight Costs and the Corn-Oil Price Relationship'. Review of Agricultural Economics, 30(3): 397-410.

de Gorter, H., and D. R. Just (2009a). 'The Welfare Economics of a Biofuel Tax Credit and the Interaction Effects with Price Contingent Farm Subsidies'. American Journal of Agricultural Economics, 91(2): 477-88.

de Gorter, H., and D. R. Just (2009b). 'The Economics of a Blend Mandate for Biofuels'. American Journal of Agricultural Economics, 91(3): 738-50.

de Gorter, H., and D. R. Just (2010a). 'The Social Costs and Benefits of Biofuels: The Intersection of Environmental, Energy and Agricultural Policy'. Applied Economic Perspectives and Policy, 32(1): 4-32. Available at: www.aepp.oxford journals.org/content/32/1/4.full.pdf+html

de Gorter, H., and D. R. Just (2010b). 'Ethanol and Corn Prices: The Role of US Tax Credits, Mandates and Import Tariffs'. In V. Eldon Ball, R. Fanfani and L. Gutierrez (eds), The Economic Impact of Public Support to Agriculture: An International Perspective. Studies in Productivity and Efficiency 7. Springer. Available at: link.springer.com/chapter/10.1007/978-1-4419-6385-7_9

de Gorter, H., D. Drabik, and D. R. Just (2011). 'The Economics of a Blender's Tax Credit versus a Tax Exemption: The Case of US. "'Splash and Dash" Biodiesel Exports to the European Union'. Applied Economic Perspectives and Policy, 33(4): 510-27.

de Gorter, H., D. Drabik, and E. M. Kliauga (2012). 'Why Ethanol Prices Are So High in Brazil'. Biofuels, 3(4): 371-73.

de Gorter, H., D. Nielson, and G. C. Rausser (1992). 'Productive and Predatory Public Policies: Research Expenditures and Producer Subsidies in Agriculture'. American Journal of Agricultural Economics, 74(1): 27-37.

Dornbusch, R. (1976). 'Expectations and Exchange Rate Dynamics'. Journal of Political Economy, 84: 1161-76.

Drabik, D. (2011). 'The Theory of Biofuel Policy and Food Grain Prices'. Charles H. Dyson School of Applied Economics and Management Working Paper 2011-20. Cornell University. Available at: www.dyson.cornell.edu/research/researchpdf/wp/2011/CornellDyson-wp1120.pdf

Economic Report of the President (1987). Washington, DC: US Government Printing Office. Available at: www.presidency.ucsb.edu/economic_reports/1987.pdf

Enders, W., and M. T. Holt (2012). 'Sharp Breaks or Smooth Shifts? An Investigation of the Evolution of Primary Commodity Prices'. American Journal of Agricultural Economics, 94: 659-73.

Foster, W. E., and G. C. Rausser (1991). 'Farmer Behavior under Risk of Failure'. American Journal of Agricultural Economics, 73(2): 276-88.

Foster, W. E., and G. C. Rausser (1993). 'Price Distorting Compensation Serving the Consumer and Taxpayer Interest’. Public Choice, 77(2): 275-91. 
Gardner, B. L. (1992). 'Changing Economic Perspectives on the Farm Problem'. Journal of Economic Literature, 30: 62-101.

Hahn, R. W. (2008). 'Ethanol: Law, Economics, and Politics'. Stanford Law and Policy Review, 19(3): 434-71.

Hochman, G., D. Rajagopal, G. Timilsina, and D. Zilberman (2011). 'The Role of Inventory Adjustments in Quantifying Factors Causing Food Price Inflation’. WB Policy Research Working Paper 5744. Washington, DC: World Bank.

Innes, R. D., and G. C. Rausser (1989). 'Incomplete Markets and Government Agricultural Policy’. American Journal of Agricultural Economics, 71(4): 915-31.

Johnson, R. L., and G. D. Libecap (2001). 'Information Distortion and Competitive Remedies in Government Transfer Programmes: The Case of Ethanol'. Economics of Governance, 2(2): 101-34.

Kliauga, E. M., H. de Gorter, and D. R. Just (2011). 'Measuring the Subsidy Component of Biofuel Tax Credits and Exemptions'. In A. Schmitz et al. (eds), The Economics of Alternative Energy Sources and Globalization. United Arab Emirates: Bentham Science Publishers. Available at: www.libro.eb20.net/Reader/rdr.aspx?b=864190

Lapan, H. E., and G. Moschini (2012). 'Second-Best Biofuel Policies and the Welfare Effects of Quantity Mandates and Subsidies'. Journal of Environmental Economics and Management, 63(2): 224-41.

Lawrence, R. Z. (2010). 'How Good Politics Results in Bad Policy: The Case of Biofuel Mandates'. Harvard Kennedy School of Government Faculty Research Working Paper Series RWP10-044. Cambridge, MA: Harvard.

Mitchell, D. (2008). 'A Note on Rising Food Prices'. WB Policy Research Working Paper 4682. Washington, DC: Development Prospects Group, World Bank.

Okum, A. M. (1975). 'Inflation: Its Mechanics and Welfare Costs'. Brookings Papers on Economic Activity, 2: 351-401.

Rajagopal, D., and D. Zilberman (2007). 'Review of Environmental, Economic and Policy Aspects of Biofuels'. WB Policy Research Working Paper WPS4341. Washington, DC: Development Research Group, World Bank.

Rausser, G. C. (1992). 'Predatory Versus Productive Government: The Case of U.S. Agricultural Policy’. Journal of Economic Perspectives, 6(3): 133-57.

Rausser, G. C. (1995). GATT Negotiations and the Political Economy of Policy Reform. Berlin and New York: Heidleberg and Springer-Verlag.

Rausser, G. C., and W. E. Foster (1990). 'Political Preference Functions and Public Policy Reform'. American Journal of Agricultural Economics, 72(3): 642-52.

Rausser, G. C., J. Swinnen, and P. Zusman (2011). Political Power and Economic Policy: Theory, Analysis, and Empirical Applications. Cambridge: Cambridge University Press.

Rausser, G. C., J. A. Chalfant, H. A. Love, and K. G. Stamoulis (1986). 'Macroeconomic Linkages, Taxes, and Subsidies in the U.S. Agricultural Sector'. American Journal of Agricultural Economics, 68(2): 399-412.

Rausser, G. C., G. D. Adams, W. D. Montgomery, and A. E. Smith (2004). 'Social Costs of an MTBE Ban in California'. Giannini Foundation Report 349. Berkeley: University of California. 
Serra, T. (2012). 'Biofuel-Related Price Transmission Literature: A Review'. Castelldefels: Centre de Recerca en Economia I Desenvolupament Agroalimentaris (CREDA). Unpublished manuscript.

Slayton, T. (2010). 'The "Diplomatic Crop", or How the US Provided Critical Leadership in Ending the Rice Crisis'. In D. Dawe (ed.), The Rice Crisis: Markets, Polices and Food Security London and Washington, DC: Food and Agriculture Organization Rome and Earthscan Publishing.

Tyner, W. E. (2008). 'The US Ethanol and Biofuels Boom: Its Origins, Current Status, and Future Prospects'. BioScience, 58(7): 646-53.

Wright, B. D. (2011). 'The Economics of Grain Price Volatility'. Applied Economic Perspectives and Policy, 33(1): 32-58.

Yano, Y., D. Blandford, and Y. R. Surry (2010). 'The Impact of Feedstock Supply and Petroleum Price Variability on Domestic Biofuel and Feedstock Markets - The Case of the United States'. Swedish University of Agricultural Sciences (SLU) Working Paper 2010/3. Uppsala: SLU.

Yano, Y., D. Blandford, and Y. R. Surry (2011). 'Alternative Domestic and Trade Policies for Biofuels and Market Variability in the United States'. In Andrew Schmitz et. al (eds), The Economics of Alternative Energy Sources and Globalization. United Arab Emirates: Bentham Science Publishers. Available at: libro.eb20.net/Reader/rdr.aspx?b=864190

Zilberman, D., G. Hochman, D. Rajagopal, S. Sexton, and G. Timilsina (2012). 'The Impact of Biofuels on Commodity Food Prices: Assessment of Findings'. American Journal of Agricultural Economics, 1-7 (June 7). Available at: doi: 10.1093/ajae/aas037

Zulauf, C., and D. Orden (2012). 'US Farm Policy and Risk Assistance: The Competing Senate and House Agriculture Committee Bills of July 2012'. ICTSD Programme on Agricultural Trade and Sustainable Development, Issue Paper No. 44 (September). 


\section{Data sources}

\section{(a) Figures 1 and 2}

- $\quad$ Corn price No 2 yellow US - Central IL \$/bushel www.ers.usda.gov/data-products/feed-grains-database/feed-grains-yearbooktables.aspx

- $\quad$ Ethanol price Nebraska rack \$/gallon www.neo.ne.gov/statshtml/66.html

- $\quad$ Oil price World Bank Pink Sheets www.econ.worldbank.org/WBSITE/EXTERNAL/EXTDEC/EXTDECPROSPECTS /0,,contentMDK:21574907 menuPK:7859231 pagePK:64165401 piPK:64165026 $\sim$ theSitePK:476883,00.html

- $\quad$ Ethanol capacity and under construction (million gallons) Renewable Fuel Association, www.ethanolrfa.org/pages/statistics\#C

(b) Figure 3

- $\quad$ Corn price Iowa Farm price \$/bushel

- $\quad$ Ethanol price Iowa \$/gallon CARD, Iowa State University www.card.iastate.edu/research/bio/tools/hist_eth_gm.aspx

\section{(c) Figures 4, 5 and 6}

- $\quad$ Wheat price \$/tonne [(US), no. 1, hard red winter, ordinary protein, export price delivered at the US Gulf port for prompt or 30 days shipment]

- $\quad$ Rice price Rice [(Thailand), 100\% broken, A.1 Super, government standard, f.o.b. Bangkok]

- $\quad$ Corn price \$/bushel [Maize (US), no. 2, yellow, f.o.b. US Gulf ports] World Bank Pink Sheets, www.econ.worldbank.org/WBSITE/EXTERNAL/EXTDEC /EXTDECPROSPECTS/0,,contentMDK:21574907 menuPK:7859231 pagePK:641 65401 piPK:64165026 theSitePK:476883,00.html 